\title{
Geociênceiasas
}

\section{Síntese sobre ofiolitos: evolução dos conceitos}

\section{Synthesis about ophiolites: evolution of concepts}

\author{
Gláucia Nascimento Queiroga \\ Professora do Departamento de Geologia, \\ Escola de Minas - UFOP. \\ glauciaqueiroga@yahoo.com.br
}

\section{Marcos Tadeu de Freitas Suita \\ Professor do Departamento de Geologia, Escola de Minas - UFOP. \\ suita@degeo.ufop.br}

\section{Antônio Carlos Pedrosa-Soares \\ Professor do Departamento de Geologia, CPMTC-IGC-UFMG. \\ pedrosa@igc.ufmg.br}

\section{Maximiliano de Souza Martins \\ Professor do Departamento de Geologia, CGE-CPMTC-IGC-UFMG. \\ maximilianomartins@yahoo.com.br}

\section{Marco Aurélio Piacentini Pinheiro \\ Geólogo da CPRM-SUREG-BH, \\ Doutorando em Evolução Crustal e \\ Recursos Naturais do Departamento \\ de Geologia, Escola de Minas - UFOP. \\ marcoaureliopp@yahoo.com.br}

\section{Resumo}

Ofiolitos são fragmentos de antigas litosferas oceânicas formados em margens de placa construtivas ou divergentes transformantes. Por meio de extensos falhamentos de empurrão, esses corpos ou parte deles são colocados na crosta continental, dentro de pacotes de rochas dos cinturões orogênicos, em estado sólido, mas podendo estar, ainda, relativamente quentes. Os possíveis ambientes produtores de litosfera oceânica incluem cadeias meso-oceânicas, bacias relacionadas a arcos-de-ilhas juvenis e bacias de retroarco. Ofiolitos de idade fanerozoica são abundantes em cinturões orogênicos ao redor do mundo, enquanto que os remanescentes oceânicos do Pré-Cambriano são pouco comuns e encontram-se distribuídos, principalmente, na Finlândia, Canadá, Marrocos, Arábia Saudita, Egito, Rússia, Brasil e China. Diversos registros de remanescentes oceânicos pré-cambrianos de diferentes idades foram reconhecidos no Brasil. A maioria desses corpos situa-se nas faixas orogênicas brasilianas e registra o consumo dos oceanos neoproterozóicos. A partir do que foi exposto, esse trabalho procura sintetizar as principais informações acerca de sequências ofiolíticas, trazendo uma breve revisão de conceitos e classificações ao longo dos quase 200 anos de utilização desse termo.

Palavras-chave: Ofiolitos, definição, classificação, exemplos brasileiros e mundiais.

\begin{abstract}
Ophiolites are fragments of the ancient oceanic lithosphere formed at constructive plate margins or transforming divergent plates. Through extensive thrust faults, these bodies or part of them are emplaced into the continental crust, inside rock piles of orogenic belts, in solid state, but these bodies can be relatively warm. The possible environments which produce oceanic lithosphere include meso-oceanic ranges, basins related to juvenile island arcs and retro-arc basins. Ophiolites of the Phanerozoic age are abundant in orogenic belts around the world whilst Precambrian oceanic remnants are less common and are distributed mainly in Finland, Canada, Morocco, Saudi Arabia, Egypt, Russia, Brazil and China. Several registers of Precambrian oceanic remnants of different ages were recognized in Brazil. Most of these bodies are situated in Brazilian orogenic belts and they register the consumption of the Neoproterozoic oceans. This paper aims to synthetize the main information about ophiolitic sequences, bringing a brief review of concepts and classifications along the 200-year use of this term.
\end{abstract}

Keywords: Ophiolites, definition, classification, Brazilian and world examples.

\section{Definição e sumário da evolução dos conceitos}

Ofiolitos são fragmentos de crosta oceânica e manto formados em centros de espalhamento e preservados no continente (Moores, 2003).
O termo ofiolito (do grego: ophios = serpente e lithos = rocha ou pedra) foi utilizado pela primeira vez em 1813 , pelo mineralogista francês Alexandre Brong- 
niart, em referência aos serpentinitos de mélanges. O termo foi redefinido em 1821 e passou a designar uma suíte magmática, composta por rochas ultramáficas, gabro, diabásio e rochas vulcânicas, descritas na região dos Apeninos (Dilek, 2003a). Estudos iniciais, desenvolvidos previamente aos conceitos de Tectônica de Placas, correlacionavam os complexos ofiolíticos a intrusões in situ dentro de geossinclinais (e.g. Benson, 1926; Steinmann, 1905, 1927). A síntese de Steinmann (1927), por exemplo, destacou a ocorrência, nas cadeias montanhosas do Mediterrâneo, de peridotito (serpentinito), gabro e diabásio/espilito em associação com rochas sedimentares de fundo oceânico (e.g. chert, argilito e calcário), interpretando a sequência como derivada de processos ígneos consanguíneos - ou produto de diferenciação magmática durante a evolução de eugeossinclinais. Essa interpretação levou à formulação do conceito amplamente divulgado e denominado "Trindade de Steinmann", referente a uma sequência composta por serpentinito - diabásio/espilito - chert. O geólogo australiano W.N. Benson (1926) interpretava as ocorrências de peridotito e serpentinito nas cadeias montanhosas como intrusões plutônicas em rochas sedimentares dobradas de um sistema geossinclinal e utilizou o termo "Peridotitos do tipo-alpino" para identificar a sequência ultramáfica. Essa interpretação, no entanto, diferia daquela apresentada por Steinmann (1927) e propunha que Peridotitos do tipo-alpino não tivessem uma conexão espacial, temporal e genética com as rochas gabróicas, diabásicas e vulcânicas (espilíticas) comumente encontradas em uma associação ofiolítica. $\mathrm{O}$ termo peridotito do tipo-alpino, também conhecido como termo de Benson, se propagou na literatura geológica, na época, em referência aos corpos ultramáficos irregulares a elípticos que ocorriam em cinturões montanhosos, submetidos a processos de diferenciação in situ.

Em seu artigo da Geological Society of America - Special Paper 62, Hess (1955) criticou o conceito de ofiolito utilizado por Steinmann (1927) enfatizando "é confusa a relação entre os diversos membros de uma sequência ofiolítica frente ao ciclo tectônico". Fazendo uma correlação entre serpentinitos e peridotitos do tipo-alpino (termo de Benson) aos processos orogênicos e de formação de montanhas, Hess (1955) argumentou que os serpentinitos e as rochas da "Trindade de Steinmann" eram comuns em arcos-de-ilha e que estes representavam um estágio inicial no desenvolvimento de um sistema montanhoso do tipo-alpino. Segundo Dilek (2003a), Hess (1955) advogava uma origem em um sistema de arco-de-ilha para a associação máficoultramáfica e peridotitos serpentinizados encontrados em sistemas orogênicos. Além disso, Hess (1955) sugeriu que a Cadeia Meso-Oceânica do Atlântico representasse uma "orla de serpentina" desenvolvida como resultado de serpentinização e deserpentinização de grandes volumes de peridotito. Esse modelo, conhecido como "Crosta do tipo-Hess", sugeria que a maior parte da crosta oceânica fosse composta por serpentinitos e que a interface entre a crosta serpentinizada e o peridotito subjacente representasse a Descontinuidade Moho.

Em meados da década de 1960, o reconhecimento de enxames de dique em lençol (sheeted dikes) extensionais, da existência de uma unidade mantélica refratária representada por peridotitos com texturas de deformação de alta temperatura, da câmara magmática fóssil (fossil magma chamber) em sequências plutônicas e da natureza alóctone dos ofiolitos foi essencial para a formulação do modelo de sequência ofiolítica e da análoga "crosta oceânica-ofiolítica" no contexto da teoria emergente da Tectônica de Placas. Essa analogia foi confirmada na Primeira Conferência Penrose sobre ofiolitos, em 1972, com a definição da sequência pseudoestratigráfica ideal de um complexo ofiolítico, utilizando-se o enxame de diques em lençol como marcador do processo de espalhamento de fundo oceânico. Nessa época, o desenvolvimento de ofiolitos ao longo das cadeias meso-oceânicas (MOR) antigas era o modelo mais aceito pela comunidade geológica (ver detalhes em Dilek 2003a). Estudos geoquímicos de detalhe mudaram essa visão no início da década de 1970 e sugeriam a associação de magmas com zonas de subducção (ZSS). Miyashiro (1973) relacionou a gênese do ofiolito de Troodos (Chipre) com processos de suprassubducção em sistema de arco-deilha. O paradigma envolvendo a conceituação de complexos ofiolíticos, entretanto, somente permitiu definir ofiolitos de zona de suprassubducção no início da década de 1980. Estudos petrológicos e geoquímicos de ofiolitos mundiais ao longo das décadas de 1980 e 1990 (e.g. Serri, 1981, Leterrier et al., 1982, Nicolas, 1989) demonstraram a importância dos fluidos derivados de zonas de suprassubducção no desenvolvimento dos magmas ofiolíticos; antearco, arco embrionário e retroarco se tornaram os ambientes tectônicos mais aceitos em uma zona de suprassubducção (Dilek, 2003a, Moores, 2003, Pearce, 2003). Diversas conferências temáticas, ao longo dos últimos 30 anos, foram fundamentais para entender as sequências ofiolíticas, incluindo os Simpósios de Troodos em 1979 e 1987 (Panayiotou, 1980, Malpas et al., 1990), a Conferência de Omã em 1990 (Peters et al., 1991) e a segunda Conferência Penrose sobre ofiolitos e crosta oceânica - em conjunto com os resultados do Programa Ocean Drilling - em 1998 (Dilek et al., 2000).

\section{Pseudoestratigrafia de complexos ofiolíticos}

A sequência pseudoestratigráfica ideal de um complexo ofiolítico foi definida na primeira Conferência Penrose sobre ofiolitos, em setembro de 1972. Os participantes dessa conferência, através de investigações de campo em sequências ofiolíticas no oeste americano e, discussões acerca dos modelos europeus, produziram uma publicação contendo a definição e respectiva estratigrafia de um ofiolito (Anônimos, 1972), como mostra- do a seguir.

"Ofiolito se refere a uma associação distinta de rochas ultramáficas, máficas e sedimentares. O termo não deve ser utilizado para nomear rochas ou como uma unidade litológica em mapeamentos. Em um complexo ofiolitico completamente desenvolvido, as rochas ocorrem na seguinte sequência, do topo para a base (Figura 1):

- Associação sedimentar, composta por rochas sedimentares quimicas de mar profundo (e.g., chert, sedimentos manganesiferos ou umber e formações ferriferas) elou sedimentos detríticos pelágicos e, em determinados casos, turbiditos vulcanoclásticos. Pode ocorrer interestratificada com as rochas vulcânicas-derrames ou lavas almofadadas. - Complexo vulcânico máfico, representado por basalto em forma de almofada (pillow lava), de composição toleí- 
tica. Pode apresentar espessura muito variada e diversas vezes é cortado por diques de diabásio.

- Sheeted dikes ou enxame de diques em lençol, encontra-se em contato nitido com as rochas vulcânicas sobrejacentes, com espessuras métricas a decamétricas. Os diques apresentam composição toleitica e zonas de resfriamento assimétricas. É possivel identificar, dentro da unidade, várias gerações de diques de diabásio que se cortam mutuamente.

- Complexo máfico plutônico, dominantemente composto por rochas gabróicas. A transição deste complexo com os sheeted dikes é marcada pelo aumento das fatias de gabro associa- das aos diques. A unidade contém gabros isotrópicos, correlacionáveis a intrusões tardias, e gabros acamadados, muito comumente associados aos cumulados máfico-ultramáficos (cromita + plagioclásio + clinopiroxênio) presentes na base da unidade. É importante ressaltar a presença de corpos intrusivos de composição plagiogranítica (diorito a tonalito) associados às rochas gabróicas.

- Complexo ultramáfico, caracteristicamente remanescente de manto suboceânico, composto por proporções variáveis de harzburgito, lherzolito e dunito, usualmente com textura tectônica metamórfica (mais ou menos serpentinizada).

Contatos falhados entre unidades mapeáveis são comuns. Admitindo-se que ofiolito seja representante da litosfera oceânica, ou seja, crosta oceânica e parte do manto superior, o uso deste termo deveria ser independente da sua suposta origem (Anônimos, 1972)".

A definição da Conferência Penrose não aborda os mecanismos de posicionamento dos ofiolitos no continente. A publicação não define um complexo ofiolítico com base em ambientes tectônicos ou em sua origem ígnea. Moores (2002), em síntese sobre os ofiolitos Pré-Rodínia, aponta problemas associados com a sequência ofiolítica do tipo-Penrose; o principal é que a maioria dos complexos não apresenta a sequência completa, como prediz a definição de 1972.
Figura 1

Sequência ofiolítica completa de acordo com a definição da Conferência Penrose (Anônimos 1972), típica de centros de espalhamento rápido (Moores, 2002).

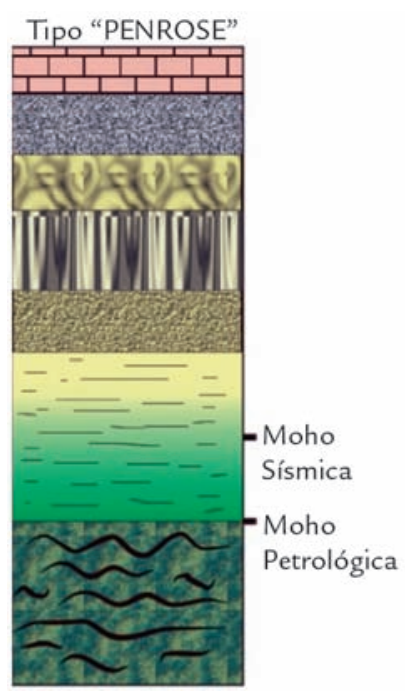

Rochas sedimentares terrestres ou marinhas rasas Sedimentos pelágicos, hemipelágicos ou vulcanogênicos Pillow lavas e fluxos extrusivos máficos Complexo de enxame de diques Gabros, dioritos ou leucogranitos maciços Serpentinitos Cumulatos máficos Cumulatos ultramáficos Ultramáficos tectônitos

\section{Ambientes de geração de ofiolitos: cadeia meso-oceânica versus zona de suprassubducção}

Complexos ofiolíticos mostram grande variedade de estrutura interna, pseudoestratigrafia e padrões geoquímicos, sugerindo distintos ambientes de geração. Ofiolitos se formam em diferentes estágios do "Ciclo de Wilson", com subsequente incorporação nas margens continentais por meio de eventos orogênicos colisionais e/ou acrescionários (obducção). É consenso entre os autores que os principais ambientes produtores de crosta oceânica incluem dorsais mesooceânicas, bacias de arcos-de-ilha juvenis, bacias de antearco e retroarco.

Conforme brevemente abordado no item 1 e aqui enfatizado, cadeias meso-oceânicas eram tidas como o centro de geração de ofiolitos até a década de 1970 . O conceito de formação de sequências ofiolíticas em bacias marginais foi primeiramente proposto por Dewey e Bird (1971 in Pearce 2003), por meio de critérios geológicos que faziam a dis- tinção entre os ambientes de dorsal e de bacia marginal. Miyashiro (1973), com base em análises químicas de elementos maiores e traços de basaltos, argumentava que o Ofiolito de Troodos (Chipre) teria sua origem associada a um ambiente de arco-de-ilha. Nessa mesma época, Pearce e Cann (1973) definiram diagramas de discriminação entre ofiolitos gerados em dorsais meso-oceânicas e em zonas de suprassubducção, utilizando elementos menores e traços (e.g. gráfico ternário Ti/100 vs. Zr vs. Yx3). Segundo Nicolas e Boudier (2003), esses diagramas foram amplamente aplicados para a maioria dos ofiolitos mundiais, sendo que o resultado imediato foi a conclusão de que, pelo menos aparentemente, a maioria dos remanescentes oceânicos tinham origem em bacias marginais. $\mathrm{O}$ termo "ofiolitos de suprassubducção" foi formalmente definido por Pearce et al. (1984), como mostrado a seguir:
"Ofiolitos de zonas de suprassubducção (ZSS) apresentam características geoquímicas de arcos-de-ilha mas a estrutura da crosta oceânica evidencia que foram formados pelo espalhamento do assoalho diretamente acima da litosfera oceânica subductada. Este tipo ofiolitico difere do MORB nas sequências mantélicas, na presença mais comum de depósitos de cromita podiforme e na cristalização de clinopiroxênio anterior ao plagioclásio, refletindo a abundância de wehrlito relativamente ao troctolito na sequência cumulática. A maioria dos mais bem preservados ofiolitos nos cinturões orogênicos é do tipo ZSS".

Pearce (2003) aponta três ambientes geradores de ofiolitos exclusivamente do tipo ZSS: subducção sob uma dorsal, subducção de uma dorsal com formação de ofiolitos em zonas de ante-arco e subducção de uma dorsal com formação de ofiolitos na placa descendente. No pri- 
meiro e segundo casos, o espalhamento oceânico ocorre no antearco; no terceiro exemplo, o espalhamento ocorre na placa subductada (Figura 2). Ainda segundo o autor, bacias de retroarco apresentam composições altamente variáveis, gradando de MORB a ZSS, com todos os termos intermediários entre os dois extremos.

Uma síntese apresentada por Shervais (2000) mostra o "ciclo de vida" de ofiolitos do tipo ZSS, considerando a evolução e o posicionamento desses corpos. De acordo com o autor, os principais eventos podem ser resumidos da seguinte maneira:

- Nascimento: formação em uma zona de subducção nascente ou reconfigurada.

- Juventude: continuada fusão da cunha mantélica e acresção crustal.

- Maturidade: início do vulcanismo do arco semiestável, frequentemente de caráter cálcio-alcalino, quando a subducção está matura e estável.

- Morte: repentino término da subducção, geralmente devido à colisão continental.

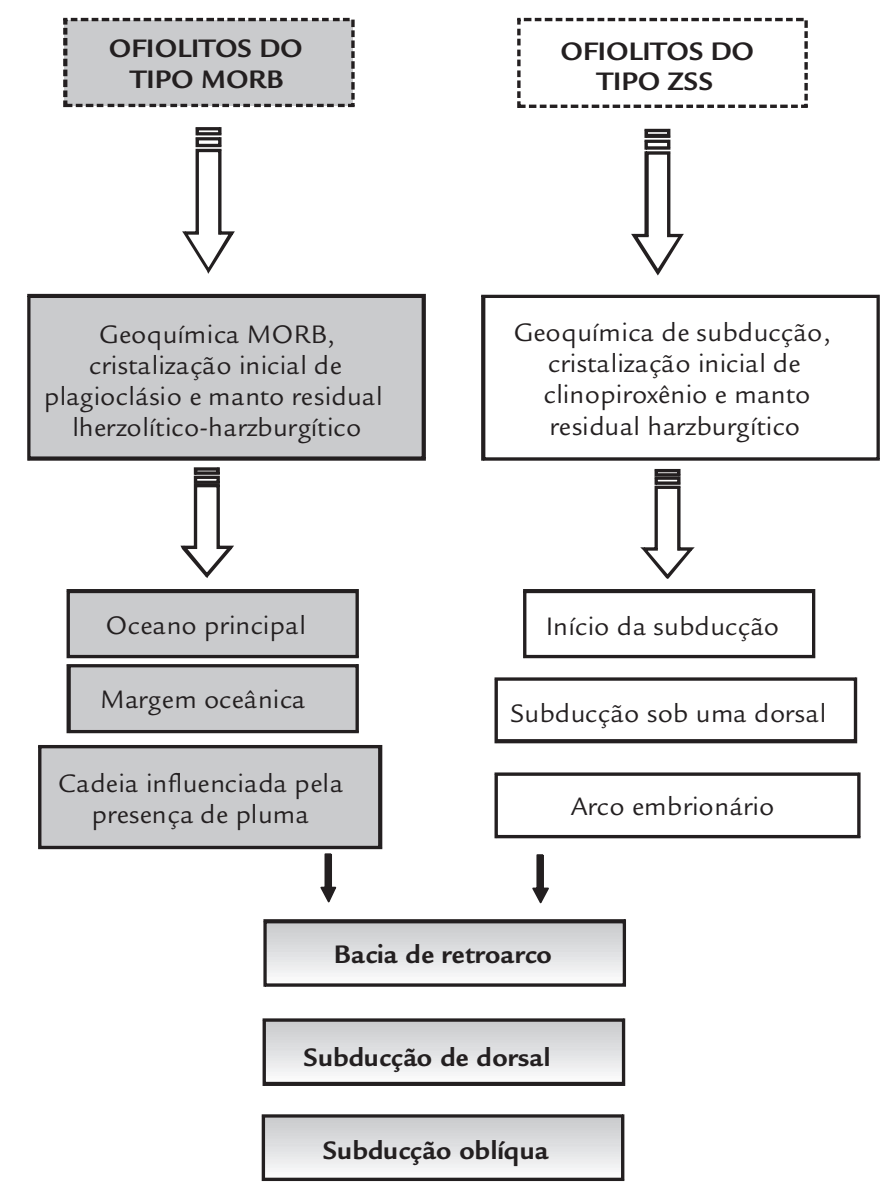

\section{Classificação de complexos ofiolíticos}

Diversos esquemas de classificação de ofiolitos, com base em características petrológicas e geoquímicas, ambientes tectônicos e padrão de posicionamento das sequências no continente, foram desenvolvidos ao longo dos últimos trinta e cinco anos. Na década de 1970, os principais trabalhos levavam em consideração, especialmente, a afinidade geoquímica

\section{Depósitos minerais em ofiolitos}

Complexos ofiolíticos são importantes fontes de $\mathrm{Zn}$ e $\mathrm{Cu}$ (em sulfetos maciços), Co e Ni (em lateritas), cromita podiforme e de rochas e minerais industriais (serpentinito e amianto). São fontes das rochas ultramáficas e vulcânicas máficas. A década de 1980 constitui um marco na história de classificação dos ofiolitos, sendo introduzido o conceito de "ambiente tectônico" aos trabalhos publicados. Uma síntese cronológica dos principais modelos classificatórios, anteriores àquele proposto por Dilek (2003a), é apresentada na Tabela 1.

potenciais para prospecção de ouro e elementos do grupo da platina ou EGP - ósmio, irídio, platina, rutênio, ródio e paládio (Castroviejo, 2004, Prichard, 2004) (Figura 3). Segundo Castroviejo
- Ressurreição: posicionamento da sequência ofiolítica em uma margem continental passiva.

Shervais (2000) ressalta que esses eventos, geralmente, progridem em ordem cronológica, mas que nem todos os ofiolitos de ZSS mostram os cinco estágios evolutivos. Os estágios do "nascimento" e da "juventude" são comuns a todos os complexos, refletindo sua formação original na placa superior de uma zona de subducção.
Figura 2

Sumário das principais características e ambientes tectônicos associados a ofiolitos do tipo MORB e ZSS (modificado de Pearce, 2003).
Um novo e moderno esquema classificatório, proposto por Dilek (2003a), considera sete tipos específicos de ofiolitos, levando-se em consideração os ambientes tectônicos de geração e os mecanismos de posicionamento dos mesmos em diferentes tipos de cinturões orogênicos (e.g. colisional versus acrescionário) (Tabela 2). 


\begin{tabular}{|c|c|c|}
\hline Autor & Base para a classificação & Descrição \\
\hline $\begin{array}{l}\text { Mesorian } \\
(1973)\end{array}$ & $\begin{array}{c}\text { Considerou a distribuição } \\
\text { dos diques máficos e a } \\
\text { afinidade geoquímica das } \\
\text { lavas. }\end{array}$ & $\begin{array}{l}\text { Subdividiu os ofiolitos em } 3 \text { grupos: } \\
\text { - Tipo Troodos: lavas toleíticas. } \\
\text { - Tipo Pindos: lavas cálcio-alcalinas. } \\
\text { - Tipo Antalya: lavas alcalinas. }\end{array}$ \\
\hline $\begin{array}{l}\text { Nicolas \& Jackson } \\
\qquad(1972) \\
\text { Menzies \& Allen } \\
(1974)\end{array}$ & $\begin{array}{l}\text { Reconheceram um } \\
\text { padrão bimodal para } \\
\text { os peridotitos } \\
\text { do Mediterrâneo. }\end{array}$ & $\begin{array}{l}\text { Dividiram os ofiolitos em } 2 \text { subtipos: } \\
\text { - Lherzolito-harzburgito. } \\
\text { - Harzburgito. }\end{array}$ \\
\hline $\begin{array}{l}\text { Rocci et al. } \\
\text { (1975) }\end{array}$ & $\begin{array}{c}\text { Também reconheceram } \\
\text { um padrão bimodal para } \\
\text { as rochas ultramáficas. }\end{array}$ & $\begin{array}{l}\text { Consideraram } 2 \text { grupos de ofiolitos: } \\
\text { - Tipo I: Iherzolito tectonizado, plagioclásio perido- } \\
\text { tito, troctolito, gabro e Fe-gabro. } \\
\text { - Tipo II: harzburgito tectonizado, dunito, cromitito, } \\
\text { piroxenito, norito e olivina gabro. }\end{array}$ \\
\hline $\begin{array}{c}\text { Miyashiro } \\
(1975)\end{array}$ & $\begin{array}{c}\text { Utilizou as séries das } \\
\text { rochas vulcânicas como } \\
\text { parâmetro de separação. }\end{array}$ & $\begin{array}{l}\text { Classificou os ofiolitos em } 3 \text { classes distintas: } \\
\text { - Classe I: rochas vulcânicas toleíticas e/ou cálcio- } \\
\text { alcalinas (arco-de-ilha). } \\
\text { - Classe II: rochas vulcânicas toleíticas (cadeia meso- } \\
\text { oceânica e/ou arco-de-ilha). } \\
\text { - Classe III: rochas vulcânicas toleíticas e alcalinas } \\
\text { (zonas de rift). }\end{array}$ \\
\hline $\begin{array}{l}\text { Moores } \\
(1982)\end{array}$ & $\begin{array}{l}\text { Classificação das s } \\
\text { equências ofiolíticas } \\
\text { com base no ambiente } \\
\text { geológico. }\end{array}$ & $\begin{array}{l}\text { Ofiolitos subdivididos em } 2 \text { tipos: } \\
\text { - Tethyano: observados em margens passivas continen- } \\
\text { tais, com gênese associada a cadeias meso-oceânicas. } \\
\text { - Cordilherano: associados com arcos-de-ilhas e edifícios } \\
\text { vulcânicos, formados em regimes de margens conver- } \\
\text { gentes (e.g., antearco, arco ou intra-arco). }\end{array}$ \\
\hline $\begin{array}{c}\text { Boudier \& Nicolas } \\
\text { (1985) }\end{array}$ & $\begin{array}{l}\text { Levaram em } \\
\text { consideração o grau } \\
\text { de fusão parcial } \\
\text { do manto original } \\
\text { e a relação } \\
\text { "depleção mantélica vs. } \\
\text { taxa de espalhamento". }\end{array}$ & $\begin{array}{l}\text { No trabalho original, subdividiram os ofiolitos em } \\
\text { dois tipos - LOT e HOT - mas acrescentaram um } \\
\text { novo subtipo - LHOT - anos mais tarde (Nicolas \& } \\
\text { Boudier } 2003 \text { ): } \\
\text { - LOT: manto lherzolítico e menos depletado. Ex: } \\
\text { Trinity-EUA. } \\
\text { - HOT: manto harzburgítico e mais depletado. Ex: } \\
\text { Oman. } \\
\text { - LHOT: tipo harzburgito-lherzolito, com seção man- } \\
\text { télica composta por peridotitos hipoabissais, típico } \\
\text { de espalhamento lento. Ex: Newfoundland-Canadá; } \\
\text { Josephine-EUA. }\end{array}$ \\
\hline $\begin{array}{l}\text { Ishiwatari } \\
\text { (1985) }\end{array}$ & $\begin{array}{l}\text { Utilizou os mesmos } \\
\text { princípios de Boudier \& } \\
\text { Nicolas (1985) }\end{array}$ & $\begin{array}{l}\text { Subdividiu os ofiolitos em } 3 \text { tipos: } \\
\text { - Tipo Ligúria: coincidente cm o LOT de Boudier \& } \\
\text { Nicolas (1985). } \\
\text { - Tipo Papua: coincidente com o HOT. } \\
\text { - Tipo Yakuno: intermediário entre os dois anteriores, } \\
\text { anos depois denominado LHOT. }\end{array}$ \\
\hline $\begin{array}{l}\text { Nicolas } \\
(1989)\end{array}$ & $\begin{array}{l}\text { Baseou-se em ambientes } \\
\text { tectônicos de } \\
\text { posicionamento } \\
\text { dos remanescentes } \\
\text { oceânicos para } \\
\text { desenvolver } \\
\text { sua classificação. }\end{array}$ & $\begin{array}{l}\text { Separou os ofiolitos em } 3 \text { tipos: } \\
\text { - Tipo I: ofiolitos encaixados em margens passivas } \\
\text { continentais. Ex: Semail-Oman e Papua-Nova Guiné. } \\
\text { - Tipo II: ofiolitos incorporados em margens ativas } \\
\text { continentais do Cinturão do Pacífico. Ex: Complexo } \\
\text { da Califórnia-EUA. } \\
\text { - Tipo III: ofiolitos de zonas de sutura que ocorrem em } \\
\text { regiões de colisão continente-continente e arco-conti- } \\
\text { nente. Ex: ofiolitos Caledonianos e Uralianos. }\end{array}$ \\
\hline $\begin{array}{l}\text { Coleman } \\
(2000)\end{array}$ & $\begin{array}{l}\text { Interpretou os ofiolitos } \\
\text { da Califórnia à luz de } \\
\text { novos conceitos e } \\
\text { utilizou a história } \\
\text { evolucionária, relações } \\
\text { estratigráficas, } \\
\text { características } \\
\text { petrológicas e químicas, } \\
\text { dados geofísicos e } \\
\text { idades de cristalização } \\
\text { magmática para realizar } \\
\text { a sua classificação. }\end{array}$ & $\begin{array}{l}\text { Ofiolitos divididos em } 5 \text { grupos distintos: } \\
\text { - Tipo I: ofiolitos de zona de suprassubducção intrao- } \\
\text { ceânica. } \\
\text { - Tipo II: escamas de rochas máfico-ultramáficas as- } \\
\text { sociadas a um ambiente de rift continental. } \\
\text { - Tipo III: peridotitos abissais, provavelmente origi- } \\
\text { nados em zonas de fratura, alojados em mélanges } \\
\text { acrescionárias. } \\
\text { - Tipo IV: rochas ofiolíticas de cadeias meso-oceânicas } \\
\text { que foram incorporadas na cunha acrescionária } \\
\text { Franciscana. } \\
\text { - Tipo V: escamas de crosta oceânica tectonicamente } \\
\text { alojadas na base da margem continental em zonas de } \\
\text { subduccão. }\end{array}$ \\
\hline
\end{tabular}




\begin{tabular}{|c|c|}
\hline Tipo Ofiolítico & Principais Características \\
\hline $\begin{array}{c}\text { Tipo } \\
\text { Liguriano }\end{array}$ & $\begin{array}{l}\text { Caracteriza-se pela existência de peridotitos altamente serpentinizados, intrudidos } \\
\text { e/ou cobertos por pequeno a moderado volume de gabros, diques locais e } \\
\text { pillow lavas. Apresenta estrutura interna do tipo-Hess. Provavelmente, se forma } \\
\text { durante os estágios iniciais de abertura de uma bacia oceânica, com posterior rift } \\
\text { continental. Está originalmente situado em posição pericontinental adjacente às } \\
\text { margens continentais rifteadas. Os exemplos característicos desse tipo ocorrem } \\
\text { nos Apeninos Setentrionais (região da Ligúria) e nos Alpes Ocidentais. }\end{array}$ \\
\hline $\begin{array}{c}\text { Tipo } \\
\text { Mediterrâneo }\end{array}$ & $\begin{array}{l}\text { É caracterizado pela presença da sequência pseudoestratigráfica, praticamente } \\
\text { completa, de um ofiolito idealizado segundo a definição da Conferência } \\
\text { Penrose. Apresenta uma sequência mantélica composta tanto por peridotitos de } \\
\text { composição harzburgítica-Iherzolítica quanto dominantemente harzburgítica. As } \\
\text { rochas plutônicas, gabroicas, apresentam contatos intrusivos e/ou falhados com } \\
\text { a unidade de enxame de diques em lençol. Esses diques são os alimentadores } \\
\text { das rochas vulcânicas sobrejacentes que incluem lavas almofadadas ou derrames. } \\
\text { A cobertura sedimentar é geralmente composta por rochas pelágicas (calcário } \\
\text { e/ou chert). A evolução desse tipo de ofiolito inclui espalhamento do assoalho } \\
\text { oceânico, magmatismo e tectonismo na placa sobrejacente (upper plate) em } \\
\text { zonas de subducção intraoceânica, sendo os complexos ofiolíticos formados } \\
\text { em ambientes de ante-arco, arco juvenil e/ou retroarco. Os melhores exemplos } \\
\text { incluem os ofiolitos de Troodos - Chipre, Kizildag - Turquia, Semail - Oman, } \\
\text { Xigaze - Tibet e Bay of Islands - Newfoundland, Canadá. }\end{array}$ \\
\hline $\begin{array}{c}\text { Tipo } \\
\text { Serrano }\end{array}$ & $\begin{array}{l}\text { Apresenta uma trajetória evolucionária complexa e poligenética. O exemplo mais } \\
\text { representativo deste tipo é o "ofiolito de arco" (arc ophiolite), de idade Jurássica, } \\
\text { exposto na porção ocidental da serra Nevada, Califórnia. Esse ofiolito contém } \\
\text { rochas vulcânicas, plutônicas e hipoabissais, com enxame de diques em lençol } \\
\text { bem desenvolvido localmente. As rochas vulcânicas variam de basalto e basalto } \\
\text { andesítico a dacito e riolito; rochas vulcanoclásticas, incluindo deposição } \\
\text { subaérea, estão distribuídas ao longo de todo o terreno, indicando a construção } \\
\text { de um edifício vulcânico durante a evolução desse ofiolito. Alguns ofiolitos do } \\
\text { Japão, Filipinas e Cuba, que apresentam evolução poligenética similar à descrita } \\
\text { anteriormente, podem pertencer a esse grupo. }\end{array}$ \\
\hline & $\begin{array}{l}\text { É caracterizado pelo conjunto de ofiolitos "Rocas Verdes", localizado no Chile, } \\
\text { e representa uma crosta oceânica fóssil, relativamente autóctone, circundada } \\
\text { por rochas cristalinas dos Andes. Os ofiolitos de Rocas Verdes apresentam, do } \\
\text { topo para a base, a seguinte sequência de rochas: vulcânicas máficas (2-3 km de } \\
\text { espessura), representadas por lavas almofadadas e brechas vulcânicas; enxame } \\
\text { de diques em lençol (300-500m de espessura), composto por diabásio maciço } \\
\text { e gabros de granulação grossa. Peridotitos mantélicos não estão expostos. Esses } \\
\text { ofiolitos se formam em bacias de retroarco extensionais, em ambiente "ensiálico" } \\
\text { num arco magmático. Esse tipo ofiolítico pode ser comum nos Pontides (Turquia) } \\
\text { e nos cinturões orogênicos paleozóicos da Ásia Central. }\end{array}$ \\
\hline $\begin{array}{c}\text { Tipo } \\
\text { Macquarie }\end{array}$ & $\begin{array}{l}\text { É representado por uma única ocorrência na ilha oceânica de Macquarie - sudeste } \\
\text { da Tasmânia. Esse tipo ofiolítico representa um fragmento de cadeia meso- } \\
\text { oceânica praticamente in situ e inclui, do topo para a base: rochas basálticas } \\
\text { extrusivas intercaladas com rochas sedimentares vulcanoclásticas; doleritos ( } \\
1,5 \mathrm{~km} \text { de espessura); zona transicional composta por microgabro (transição entre } \\
\text { sheeted dikes e seção plutônica máfica); gabro de granulação grossa, maciço e/ } \\
\text { ou bandado com rochas ultramáficas associadas; e sucessões peridotíticas. Tem } \\
\text { uma estratigrafia similar a definida pela Conferência Penrose. }\end{array}$ \\
\hline $\begin{array}{c}\text { Tipo } \\
\text { Caribenho }\end{array}$ & $\begin{array}{l}\text { Representa crosta oceânica gerada em Grandes Províncias Ígneas (Large Igneous } \\
\text { Province - LIP) e associada a platôs oceânicos. A estrutura interna e a estratigrafia } \\
\text { dos fragmentos desses platôs, alojadostectonicamente, são bastante heterogêneos } \\
\text { mas contêm muitas das subunidades ofiolíticas, incluindo derrames e lavas } \\
\text { almofadadas, gabros isotrópicos a bandados, dunitos com bandas de Iherzolito, } \\
\text { olivina websterito, e olivina gabronorito nos níveis inferiores. Exemplos desse tipo } \\
\text { são os ofiolitos de idade Cretácea do Caribe (e.g. Costa Rica e Venezuela) e os } \\
\text { ofiolitos do Japão (Platô Sorachi) e do Equador (Formação Piñon). }\end{array}$ \\
\hline $\begin{array}{c}\text { Tipo } \\
\text { Franciscano }\end{array}$ & $\begin{array}{l}\text { Está espacialmente associado com complexos acrescionários de margens } \\
\text { ativas e, via de regra, encontra-se tectonicamente intercalado com mélanges e } \\
\text { rochas metamórficas de alto grau, típicas de zonas de subducção. Os Ofiolitos } \\
\text { Franciscanos incluem fragmentos de peridotitos abissais, gabros e basaltos, } \\
\text { possivelmente originados em zonas de fratura; escamas de crosta oceânica com } \\
\text { origem em cadeias meso-oceânicas (pillow lavas e gabros) e/ou fragmentos } \\
\text { desmantelados de arcos-de-ilha. Essas rochas oceânicas estão localmente } \\
\text { associadas com rochas sedimentares pelágicas - hemipelágicas (chert, calcário) } \\
\text { e terrígenas. Blocos de xisto azul ocorrem nesse complexo acrescionário. } \\
\text { Os melhores exemplos ocorrem na Califórnia (Complexo Franciscano), nas } \\
\text { ilhas japonesas (ofiolitos de Oeyama e Yakuno) e no complexo acrescionário } \\
\text { ordoviciano - devoniano da Precordilheira ocidental na Argentina. }\end{array}$ \\
\hline
\end{tabular}

Tabela 2

Esquema classificatório de complexos ofiolíticos segundo Dilek (2003a). 
integra a sequência e (b) transformações ou adições que essas concentrações irão sofrer ao longo da história orogênica do ofiolito, incluindo metamorfismo, deformação, hidrotermalismo, intemperismo e erosão.

Uma síntese das principais mineralizações encontradas em uma sequência ofiolítica completa e ideal, de acordo com a definição da Conferência Penrose, é apresentada a seguir. Na seção ultramáfica, os depósitos de cromita, geralmente, localizam-se na base da sequência de cumulados, sob a forma de camadas, ou como pods (cromita podiforme), na sequência harzburgítica - que pode estar tectonizada ou não (Paixão, 2009; Figura 3). Depósitos de asbestos estão associados a fraturas preenchidas por crisotila nos peridotitos mantélicos serpentinizados e podem alcançar espessuras de dezenas de metros. Níquel e cobalto ocorrem como resultado de enriquecimento supergênico nas rochas ultramáficas, formando grandes depósitos econômicos - Ni laterítico em Cuba e Nova Caledônia e Co laterítico em Bou Azzer-Marrocos, por exemplo.
Os elementos do grupo da platina (EGP) se concentram nas rochas ígneas máficas e ultramáficas (Figura 3). Todos elementos são, marcantemente, calcófilos e siderófilos; Os, Ir e Ru estão associados, como sulfetos ou ligas metálicas, e formam inclusões em cromititos; $\mathrm{Pt}$, Pd e Rh se concentram fora deles como sulfetos. Na Faixa Brasília, em Abadiânia, em zonas de hidrotermalismo, os teores de Au chegam a 8272ppb e os de EGP, até 252ppb (e.g., Suita et al., 2004). Os ofiolitos ricos em EGPs são os formados por altas taxas de fusão mantélica, que originam magmas boniníticos (e.g. zonas de suprassubducção). Neste caso, os platinóides se concentram na cristalização por processos magmáticos. Os ofiolitos formados por taxa de fusão mantélica insuficiente para liberar os EGPs são os do tipo MORB, como Lizard - Cornwall, Reino Unido. Minerais do grupo da platina $(M G P)$ também são encontrados nos ofiolitos e compreendem fases magmáticas, como laurita $\left(\mathrm{RuS}_{2}\right)$, sulfetos de Pt e Pd e liga Os-Ir (Prichard, 2004).

Complexos ofiolíticos exibem ca- racterísticas propícias para a formação de depósitos do tipo sulfeto maciço hidrotermal-vulcanogênico (VHMS), fontes de $\mathrm{Cu}, \mathrm{Zn} \pm \mathrm{Au}$ (Figura 3). Esses depósitos mostram acumulações estratiformes de sulfetos formados pela precipitação de fluidos hidrotermais em um ambiente submarino e ocorrem em terrenos caracterizados pela presença de rochas vulcânico-vulcanoclásticas e sedimentos associados (Sangster, 1998). Cerca de 20\% dos depósitos mundiais do tipo VHMS estão encaixados em sequências ofiolíticas, com origem em cadeias meso-oceânicas e, subordinadamente, em zonas de subducção intraoceânicas e bacias de retroarco. Guias de exploração de depósitos VMS em ofiolitos incluem: (a) identificação de um estrato vulcânico submarino; a presença de pillow lavas e de sedimentos químicos deve ser confirmada na área de prospecção; e (b) alguma evidência de atividade exalativa deve ser observada. Camadas ou lentes de chert devem ser estudadas com base em elementos com assinatura geoquímica exalativa, tais como $\mathrm{Mn}, \mathrm{Fe}, \mathrm{Ba}, \mathrm{Zn}$ e $\mathrm{Pb}$ (Sangster, 1998).

\begin{abstract}
Figura 3
Coluna esquemática de uma seção ofiolítica evidenciando a distribuição dos principais depósitos minerais (Castroviejo, 2004, Prichard, 2004, Suita et al., 2004).
\end{abstract}

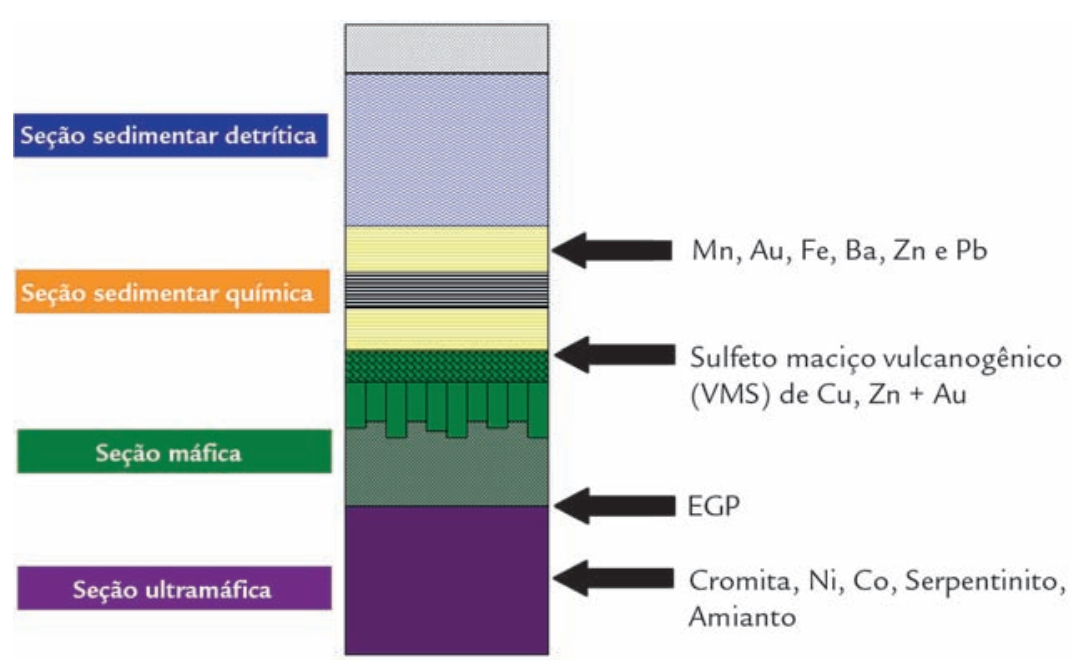

\section{Distribuição dos cinturões ofiolíticos no tempo e no espaço}

Ofiolitos nos cinturões orogênicos ocorrem em zonas curvilíneas compostas por rochas máfico-ultramáficas (com rochas metamórficas e sedimentares associadas) e representam relictos de diferentes estágios do "Ciclo de Wilson" - abertura e fechamento de bacias oceânicas. A distribuição das sequências ofiolíticas, nos diferentes cinturões orogênicos, com determinadas faixas de idade, define pulsos ofiolíticos distintos. Esses pulsos são coincidentes com a época dos maiores eventos colisionais para a formação dos supercontinentes (e.g. Rodínia,
Gondwana e Pangea), com o desmantelamento dos mesmos e com o aumento das atividades das plumas mantélicas que formam as Grandes Províncias Ígneas (Large Igneous Province - LIPs) (Dilek, 2003b, Dilek \& Robinson, 2003).

No Pré-Cambriano, em especial do Arqueano ao Mesoproterozoico, o registro de sequências ofiolíticas é pouco documentado, devido, em parte, à deformação intensa e ao retrabalhamento da crosta continental em múltiplos episódios orogênicos ao longo do tempo (Moores, 2002, Dilek, 2003b). Um estudo dos mais bem preservados complexos ofiolíticos pré-1,0 Ga - denominados "PréRodínia” - evidencia quatro intervalos de tempo principais para geração das sequências: 1,5-1,0 Ga (e.g. Pie de Palo-Argentina); 2,3-1,8 Ga (e.g. Jormua-Finlândia); ca. 2,7-2,5 Ga (e.g. Yellowknife-Estados Unidos); e ca. 3,4 Ga (e.g. JamestownÁfrica do Sul). Segundo Dilek (2003b), a realização de uma correlação entre o pulso ofiolítico Pré-Rodínia com algum evento tectônico global é muito difícil pelo limitado conhecimento sobre a história da Terra nesse período. 
O Proterozoico Superior é representado por três grandes pulsos de geração de ofiolitos - ca. $700 \mathrm{Ma}, 780-740$ Ma e 860-820 Ma. Os complexos associados a esse período concentram-se na América do Sul, África e Arábia, menos na Europa Central e Oriental, no Cáucaso Inferior, na Ásia Central e noroeste da Índia. Nos cinturões afroarábico e na América do Sul, os ofiolitos neoproterozoicos estão relacionados à evolu- ção de bacias oceânicas Pan-AfricanasBrasilides (e.g. oceano Moçambicano), como resultado da quebra do supercontinente Rodínia e na configuração do Gondwana Ocidental (Dilek, 2003a,b; Stern, 2008).

No Fanerozoico, o pulso ofiolítico mais importante situa-se no período entre 180-140 Ma, quando foram formados os ofiolitos Tethyanos, Caribenhos e alguns associados ao Círculo do Pacífico; um segundo pico importante, na geração de ofiolitos, diz respeito ao Cretáceo Superior (ca. $90 \mathrm{Ma}$, dominantemente ofiolitos Tethyanos). Pulsos ofiolíticos de segunda ordem são observados nos períodos Permiano Superior-Triássico Inferior (ca. 250-230 $\mathrm{Ma})$, Devoniano Inferior-Siluriano ( $c a$. 440-400 Ma) e Cambriano SuperiorOrdoviciano Inferior (500-460 Ma) (Dilek 2003b).

\section{Ofiolitos no Brasil}

Os remanescentes oceânicos brasileiros, em sua grande maioria, ocorrem nas faixas orogênicas brasilianas, registrando o consumo dos oceanos no Neoproterozoico, e estão associados a ambientes colisionais do tipo continente - arco-de-ilha e continente - conti- nente. Ofiolitos mais antigos, de idades mesoproterozoica e paleoproterozoica, ocorrem na Faixa Sunsás-Aguapeí, ao sul do Cráton Amazônico, e no Terreno Alto Moxotó, na Província Borborema, respectivamente (Figura 4; Suita et al., 2004). Os ofiolitos brasileiros são,

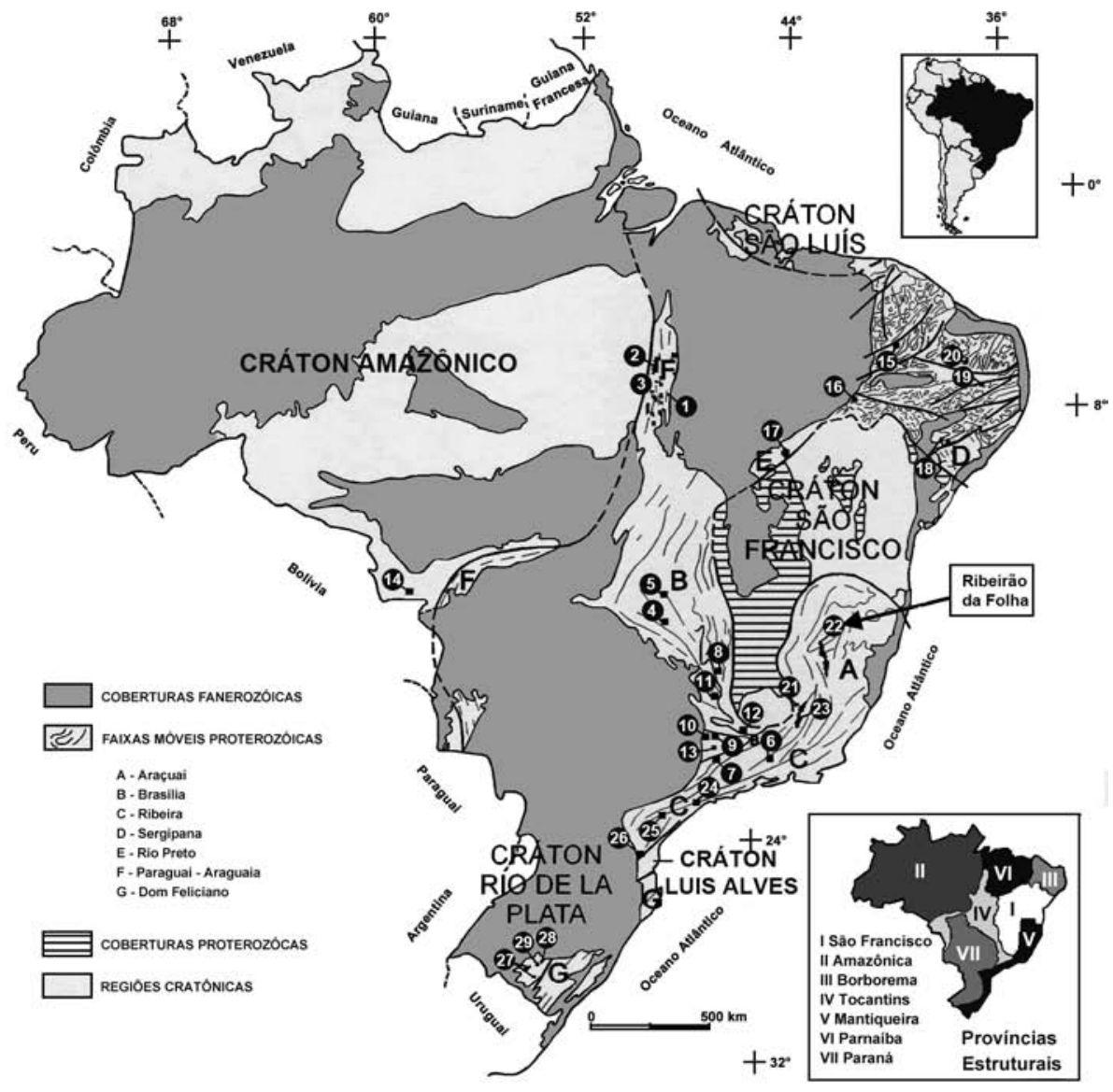

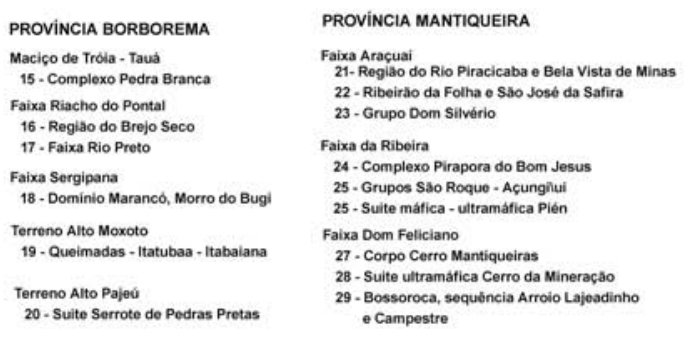

20 - Suite Serrote de Pedras Pretas
Bossoroca, sequéncia Arroio Lajoadin to e Campestre predominantemente, representados por rochas metaultramáficas e/ou metamáficas, plutônicas, acamadadas ou maciças, eventualmente com corpos de cromita podiforme, nodular ou disseminada. São corpos alóctones, desmembrados, pequenos a muito pequenos, tectonicamente

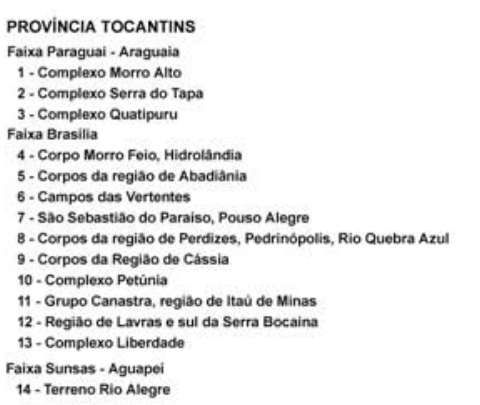

Figura 4

Localização das associações ofiolíticas nas faixas móveis brasileiras (Suita et al., 2004). 
intercalados com sequências metavulcano-sedimentares ou metassedimentares. Geralmente, esses corpos exibem metamorfismo de fácies xisto verde a anfibolito, sendo raros os de grau metamórfico mais alto (e.g. eclogitos e retroeclogitos localizados nas regiões de São Sebastião do Paraíso e Pouso Alegre, sul de Minas Gerais; Suita et al., 2004; Pinheiro \& Suita, 2009).

As sequências ofiolíticas mais conhecidas do Brasil ocorrem nas faixas Araçuaí, Brasília, Araguaia e Ribeira (Figura 4). Na Faixa Araçuaí, remanescentes de rochas de assoalho oceânico têm sido descritos na literatura geológica desde 1990. O mais completo desses registros é o ofiolito de Ribeirão da Folha - São José da Safira, uma associação tectonicamente desmembrada, composta por rochas metamáficas e metaultramáficas encaixadas em pacotes de xistos pelíticos com intercalações de metachert sulfetado, diopsidito e formações ferríferas bandadas, metamorfisados em fácies anfibolito. As características petrográficas e geoquímicas das rochas metamáficas e metaultramáficas indicam afinidade ofiolítica e origem em ambiente de fundo oceânico. Dados isotópicos Sm-
$\mathrm{Nd}$ dessas rochas indicam valores iniciais de $\varepsilon \mathrm{Nd}$ positivos $(+1,8 \mathrm{a}+6,3)$. Estudos geocronológicos $\mathrm{U}-\mathrm{Pb}$ em zircões de plagiogranito oceânico evidenciam idade de cristalização magmática de $646 \pm 3 \mathrm{Ma}$. Essa idade indica a época de geração de crosta oceânica na bacia Macaúbas, precursora do Orógeno Araçuaí (Queiroga et al., 2007, Queiroga, 2010).

No setor central da Faixa Brasília, ocorrem corpos metaultramáficos com cromititos podiformes (e.g. Abadiânia, Morro do Feio e Cromínia), que possuem anomalias de platina e/ou ouro em zonas de cisalhamento e hidrotermalismo (Suita et al., 2004). Na porção sul da Faixa Araguaia, ocorre um dos mais importantes e mais bem estudados ofiolitos brasileiros, o Complexo Quatipuru. Trata-se de um ofiolito com extensão de 40 km e largura variável entre 600 metros a 2,4 km, com orientação preferencial a N-S e algumas inflexões nas direções NE-SW e NW-SE, que originam um aspecto sigmoidal em mapa. É constituído, predominantemente, por serpentinitos com um envelope de listwanito - associação de finas camadas de talco-clorita xisto e espessas camadas de rocha sílicohematítica que predominam sobre as primeiras (Paixão, 2009). No ofiolito do Quatipuru, pods de cromitito métricos estão hospedados nas rochas ultramáficas e associam-se, espacialmente, com diques mantélicos. Ocorrências menores de lateritas enriquecidas em elementos do grupo da platina (EGP) também são relatadas por alguns autores (e.g. Suita et al., 2004).

Na Faixa Ribeira, setor central da Província Mantiqueira, os restos ofiolíticos estão representados por rochas metamáficas dos grupos São Roque e Açungui, com assinaturas desde assoalho oceânico a toleítos de arco-de-ilha e idades U-Pb entre 628 e $608 \mathrm{Ma}$ (Suita et al., 2004). Maiores detalhes sobre os complexos ofiolíticos do Brasil e respectivos potenciais metalogenéticos podem ser encontrados na síntese apresentada por Suita et al. (2004) e nos trabalhos de Strieder e Nilson (1992), Navarro e Zanardo (2005) e Pinheiro \& Suita (2008), para os complexos da Faixa Brasília; Pedrosa-Soares et al. (1998) e Queiroga et al. (2007), para os ofiolitos do Orógeno Araçuaí; Tassinari et al. (2001), para o ofiolito da Faixa Ribeira; e Paixão et al. (2008) e Paixão (2009), para o Complexo Quatipuru - Faixa Araguaia.

\section{Maciço Voykar (Montes Urais Polares, Rússia): um exemplo de ofiolito paleozoico}

O ofiolito Voykar, pouco deformado e metamorfizado se comparado aos ofiolitos precambrianos, situa-se nos Montes Urais Polares, extremo nordeste da Rússia, ao redor do paralelo $66^{\circ} \mathrm{N}$ (Figura 5).

$\mathrm{Na}$ área do rio Lagortaju ocorre a seção-tipo do ofiolito Voykar (Figura 5).
De acordo com dados da bibliografia e com aqueles obtidos em campo, pode-se admitir que o Maciço Voykar inclui, da base para o topo, os seguintes litotipos (Figura 6):

- Harzburgito: rocha residual mantélica dominante que forma a maior parte da seção ofiolítica. Dunito e, mais raramente, wherlito ocorrem associados. Na maioria das vezes, as rochas ultramáficas encontram-se serpentinizadas.

- Piroxenito e Gabro: representam cumulado ultramáfico e a seção plutônica de um edifício ofiolítico, respectivamente.
Figura 5

Localização do ofiolito Voykar Montes Urais Polares, Rússia

(ofiolito em destaque na figura; modificado de Pertsev et al. 2003).
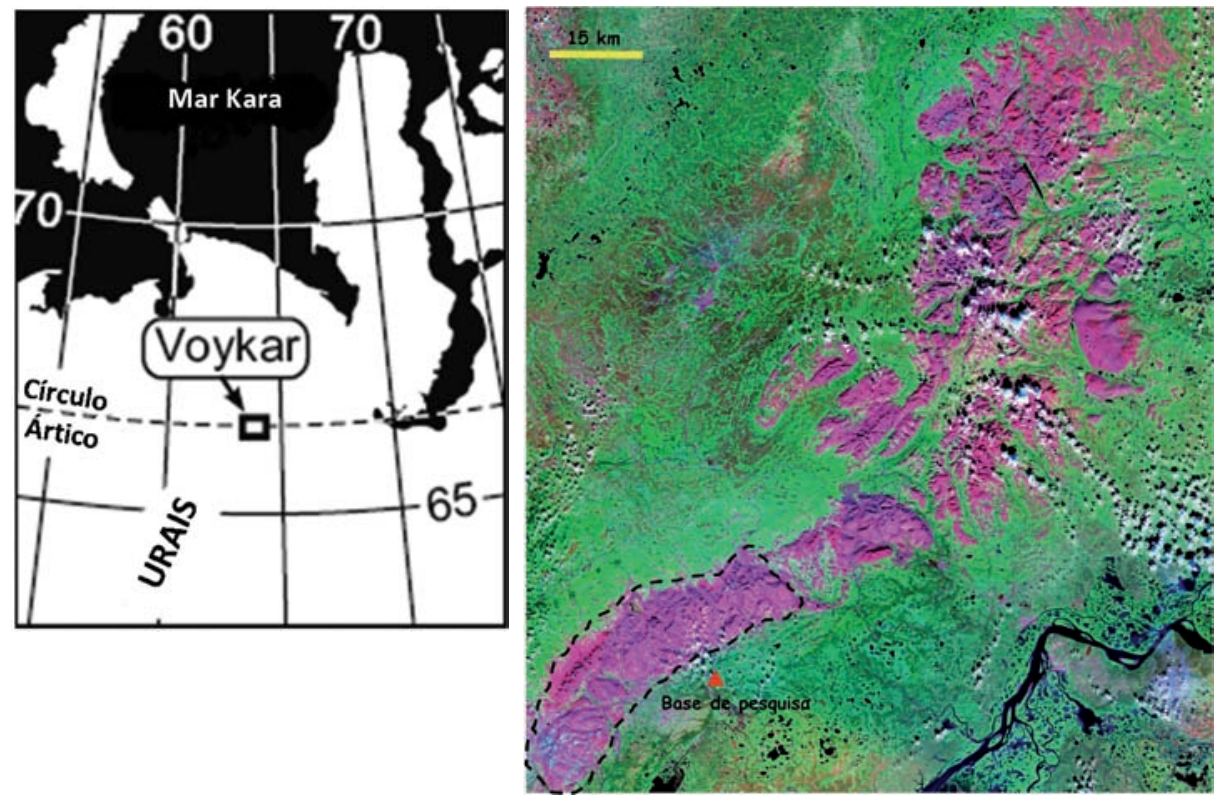


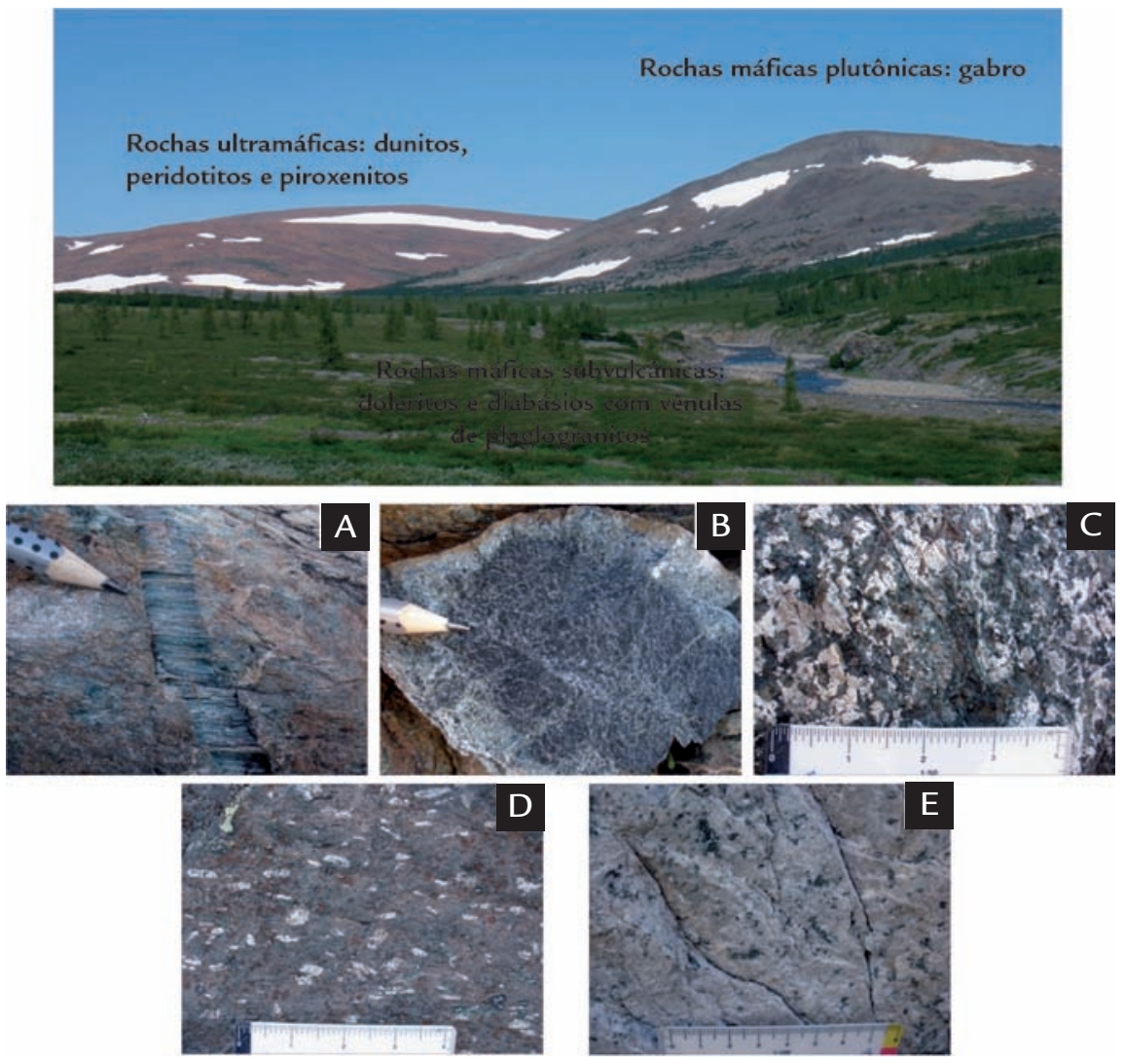

- Dolerito/diabásio: correlacionável à seção subvulcânica da sequência ofiolítica. Enfatiza-se a presença de bolsões e vênulas de plagiogranito encaixados em rochas doleríticas isotrópicas.

Dados isotópicos $\mathrm{Sm}-\mathrm{Nd}$ - rocha total, na sequência máfico- ultramáfica, disponíveis para o maciço, indicam um período de cristalização em cerca de 387 $\pm 34 \mathrm{Ma}$ (Saveliev et al., 1999). Devido à falta de precisão dessa datação e com

\section{Agradecimentos}

Os autores agradecem ao CNPq pela bolsa de doutorado da primeira autora e intuito de se obterem dados mais confiáveis, foi coletada amostra de plagiogranito para datação pelo método U-Pb LA-ICP-MS (Figura 6). Foram analisados 16 spots em 16 cristais de zircão com tamanho médio de $100 \mu \mathrm{m}$, límpidos e com poucas inclusões. Os cristais analisados possuem conteúdos de U e Th no intervalo entre $11-356 \mathrm{ppm}$ e 4-390 ppm, respectivamente, com razões ${ }^{232} \mathrm{Th} /{ }^{238} \mathrm{U}$ relativamente altas, variando entre 0,24 aos Institutos Geológicos de Moscou e da República de Komi (Rússia) pela coopera-
Figura 6

Perfil geológico ao longo do rio Lagortaju, na seção-tipo do ofiolito Voykar.

A) Peridotito serpentinizado.

B) Piroxenito.

C) Gabro.

D) Dolerito/diabásio com fenocristais de plagioclásio orientados por fluxo magmático.

E) Plagiogranito datado pelo método U-Pb (LA-ICP-MS).

e 1,09, típicas de grãos derivados de rochas magmáticas. Levando-se em consideração os cristais mais concordantes ( $<10 \%$ de discordância), conclui-se que a idade ${ }^{206} \mathrm{~Pb} / 238 \mathrm{U}$ de $427 \pm 7 \mathrm{Ma}$ é a melhor aproximação para o evento de cristalização magmática das amostras de plagiogranito e, consequentemente, para a geração de crosta oceânica no setor polar dos Montes Urais - Rússia (maiores detalhes em Queiroga et al., 2010). ção científica e realização do trabalho de campo no Maciço Voykar, Urais Polares.

\section{Referências bibliográficas}

ANÔNIMOS. Penrose Field Conference on ophiolites. Geotimes, v. 17, p. 24-25, 1972.

BENSON, W.N. The tectonic conditions accompanying the intrusion of basic and ultrabasic igneous rock. Memoirs of the National Academy of Sciences, v. 19, 90 p., 1926.

BOUDIER, F., NICOLAS, A. Harzburgite and lherzolite subtypes in ophiolitic and oceanic environments. Earth and Planetary Science Letters, v. 76, p. 84-92, 1985.

CASTROVIEJO, R. El oro en ofiolitas. In: PEREIRA, E., CASTROVIEJO, R., ORTIZ, F. (eds). Complejos Ofiolíticos en Iberoamérica: guías de prospección para metales preciosos. Madrid: Rede CYTED, 379p. cap. 2, p. 25-69, 2004.

COLEMAN, R.G. Prospecting for ophiolites along the Califórnia continental margin. In: DILEK, Y., MOORES, E., ELTHON, D., NICOLAS, A., (eds.). Ophiolites and oceanic crust: New insights from field studies and the Ocean Drilling Program. Geological Society of America, Special Paper, v. 349, p. 351-364, 2000.

DILEK, Y. Ophiolite concept and its evolution. In: DILEK, Y., NEWCOMB, S. (eds.). Ophiolite Concept and the Evolution of Geological Thought. Geological Society of America, Special Paper, v. 373, p. 1-16, 2003 a. 
DILEK, Y. Ophiolite pulses, mantle plume and orogeny. In: DILEK, Y., ROBINSON, P.T. (eds.). Ophiolites in Earth History. Geological Society of London, Special Publications, v. 218, p. 9-19, 2003 b.

DILEK, Y., ROBINSON, P.T. Ophiolites in Earth history: introduction. In: DILEK, Y., ROBINSON, P.T. (eds.). Ophiolites in Earth History. Geological Society of London, Special Publications, v. 218, p. 1-8, 2003.

DILEK, Y. et al. Ophiolites and oceanic crust: New insights from field studies and the Ocean Drilling Program. Geological Society of America, Special Paper, v. 349, 2000. 552p.

HESS, H.H. Serpentinites, orogeny and epeirogeny. In: POLDEVAART, A. (ed.). Crust of the Earth (A Symposium). Geological Society of America, Special Paper, v. 62, p. 391-408, 1955.

ISHIWATARI, A. Alpine ophiolites: product of low-degree mantle melting in a Mesozoic transcurrent rift zone. Earth and Planetary Science Letters, v. 76, p. 93-108, 1985.

LETERRIER et al. Clinopyroxene composition as a method of identification of the magmatic affinities of paleo-volcanic series. Earth and Planetary Science Letters, v. 59, p. 139-154, 1982.

MALPAS, J.et al. Ophiolites, Oceanic Crustal Analogues. In:TROODOS SYMPOSIUM. Proceedings... Nicosia: Geological Survey Department, 1990. 733p.

MENZIES, M., ALLEN, C. Plagioclase lherzolite-residual mantle relationships within two eastern Mediterranean ophiolites. Contributions to Mineralogy and Petrology, v. 45, p. 197-213, 1974.

MESORIAN, H. Idées actuelles sur la construction, l'origine et l'evolution des assemblages ophiolitiques mésogenées. Bulletin of the Geological Society of France, v. 15, p. 478-493, 1973.

MIYASHIRO, A. The Troodos ophiolitic complex was probably formed in an island arc. Earth and Planetary Science Letters, v. 19, p. 218-224, 1973.

MIYASHIRO, A. Classification, characteristics and origin of ophiolites. Journal of Geology, v. 83, p. 249-281, 1975.

MOORES, E.M. Origin and emplacement of ophiolites. Reviews of Geophysics and Space Physics, v. 20, p. 735-760, 1982.

MOORES, E.M. Pre-1 Ga (Pré-Rodínia) ophiolites: their tectonic and environmental implications. GSA Bulletin, v. 114, n. 1, p. 80-95, 2002.

MOORES, E. M. A personal history of the ophiolite concept. In: DILEK, Y., NEWCOMB, S. (eds.). Ophiolite Concept and the Evolution of Geological Thought. Geological Society of America, Special Paper, v. 373, p. 17-29, 2003.

NAVARRO, G. R. B., ZANARDO, A. Petrografia e geoquímica das rochas metaultramáficas da região de Mairipotaba, Cromínia e Pontalina, Goiás. Revista Brasileira de Geociências, v. 35, n.4, p. 483-492, 2005.

NICOLAS, A. Structures of ophiolites and dynamics of oceanic lithosphere. Netherlands: Kluwer Academic Publishers, 1989. 367p.

NICOLAS, A., JACKSON, M. Répartition em deux provinces dês peridotites dês chaînes alpines longeant la méditerranée: Implications géotectoniques. Schweizische Mineralogische Petrographische Mitteilungen, v. 52, p. 479-495, 1972.

NICOLAS, A., BOUDIER, F. Where ophiolites come from and what they tell us. In: DILEK, Y., NEWCOMB, S. (eds.). Ophiolite Concept and the Evolution of Geological Thought. Geological Society of America, Special Paper, v. 373, p. 137-152, 2003.

PAIXÃO, M.A.P. Complexo ofiolítico Quatipuru, Pará, Brasil. Brasília: Instituto de Geociências, Universidade de Brasília, 2009. 118 p. (Tese de Doutorado).

PAIXÃO, M. A. P. et al. The Neoproterozoic Quatipuru ophiolite and the Araguaia fold belt, central-northern Brazil, compared with correlatives in NW Africa. In: PAMKHURST, R. J., TROUW, R. A. J., BRITO-NEVES, B. B., WIT, M.J. de (eds.). West Gondwana: Pre-Cenozoic correlations across the south Atlantic region. Geological Society of London, Special Publications, v. 294, p. 297-318, 2008.

PANAYIOTOU, A. (ed.). Ophiolites: In: INTERNATIONAL OPHIOLITE SYMPOSIUM ON CYPRUS - 1979. Proceedings... Nicosia: Geological Survey Department, 1990. 781 p..

PEARCE, J. A. Supra-subduction zone ophiolites: The search for modern analogues. In: DILEK, Y., NEWCOMB, S. (eds.). Ophiolite Concept and the Evolution of Geological Thought. Geological Society of America, Special Paper, v. 373, p.269-293, 2003.

PEARCE, T. H., CANN, J.R. Tectonic setting of basic volcanic rocks determined using trace element analysis. Earth and Planetary Science Letters, v. 19, p. 290-300, 1973. 
PEARCE, J.A. et al. Characteristics and tectonic significance of supra-subduction zone ophiolites. Geological Society of London, Special Publications, v. 16, p. 77-94, 1984.

PEDROSA-SOARES, A.C. et al. Neoproterozoic oceanic remnants in eastern Brazil: further evidence and refutation of an exclusively ensialic evolution for the AraçuaíWest Congo Orogen. Geology, v. 26, p. 519-522, 1998.

PETERS, T.J. et al. Ophiolite genesis and evolution of the oceanic lithosphere: In: OPHIOLITE CONFERENCE ON OMAN - 1980. Proceedings... Muscat, 1991. 903 p.

PERTSEV, A. Parental melts imprited in plutonic rocks of the Voykar ophiolite, Polar Urals: evidences from clinopyroxene geochemistry. Ofioliti, v. 28, n.1, p. 33-41, 2003.

PINHEIRO, M.A.P. \& SUITA, M.T.F. Metamorfismo de fundo oceânico e alto-grau em meta-peridotitos ofiolíticos neoproterozóicos, Faixa Brasília Sul, Minas Gerais. Revista Brasileira de Geociências., v. 38, n. 4, p. 686-699, 2008.

PINHEIRO, M.A.P. \& SUITA, M.T.F. Geoquimica das metamáficas de Arantina e Alagoa. In; Congr. Bras. Geoquim., XII, Intern. Sym. Environ. Geochem., VIII, CD-Rom, Ouro Preto (MG), 2009.

PRICHARD, H.M. Elementos del grupo del platino (EGP) en complejos ofiolíticos. In: PEREIRA, E; CASTROVIEJO, R.; ORTIZ, F. (eds). Complejos Ofiolíticos en Iberoamérica: guías de prospección para metales preciosos. Madrid: Rede CYTED, 379p. cap. 3, p. 71-87, 2004.

QUEIROGA, G.N. Caracterização de restos de litosfera oceânica do Orógeno Araçuai entre os paralelos $17^{\circ}$ e $21^{\circ} \mathrm{S}$. Belo Horizonte: Instituto de Geociências, Universidade Federal de Minas Gerais, 2010. 180 p. (Tese de Doutorado).

QUEIROGA, G.N. et al. Age of the Ribeirão da Folha ophiolite, Araçuaí Orogen: the U-Pb zircon (LA-ICPMS) dating of a plagiogranite. Geonomos, v. 15, n. 1, p.61-65, 2007.

QUEIROGA, G.N. et al. First U-Pb dating of a plagiogranite from Voykar massif, Polar Urals, Russia. In: SOUTH AMERICAN SYMPOSIUM ON ISOTOPE GEOLOGY, 7. Extended Abstracts, Brasília: SBGq, 2010, v. único, p. 397-400.

ROCCI, G. et al. La dualité des ophiolites téthysiennes. Pétrologie, v. 1, p. 172-174, 1975.

SANGSTER, D.F. Volcanic-exhalative massive sulphide deposits. In: SILVA, M.G.da, MISI, A. (eds). Base Metal Deposits of Brazil. Salvador: MME/CPRM/DNPM, 108p. cap.2, p. 13-15, 1998.

SAVELIEV, A. A. et al. Plutonic to volcanic rocks of the Voykar ophiolite massif (Polar Urals): structural and geochemical constraints on their origin. Ofioliti, v. 24, n. 1, p. 21-30, 1999.

SERRI, G. The petrochemistry of ophiolitic gabbroic complexes: a key for the classification of ophiolite sinto low-Ti and high-Ti types. Earth and Planetary Science Letters, v. 52, p. 203-212, 1981.

SHERVAIS, J.W. Birth, death and resurrection: The life cycle of supra-subduction zone ophiolites. Geochemistry, Geophysics, Geosystems, v. 2, n. 2000GC000080. 2000.

STEIMANN, G. Geologische Beobachtungen in den Alpen, II. Die schart'sche Überfaltungstheorie und die geologischen Bedeutung der Tiefseeabsätze und der ophiolitische massengesteine. Bericht Naturforschung Gesellschaft Freiburg, v. 1, p. 44-67, 1905.

STEIMANN, G. Der ophiolitischen Zonen in der Mediterranean Kettengebirgen. In: INTERNATIONAL GEOLOGICAL CONGRESS, 14. Proceedings... Madrid: 1927, v. 2, p. 638-667.

STERN, R.J. Neoproterozoic crustal growth: the solid Earth system during a critical episode of Earth history. Gondwana Research, v. 14, p. 33-50, 2008.

STRIEDER, A.J. \& NILSON, A.A. Estudo petrológico de alguns fragmentos tectônicos da mélange ofiolítica em Abadiânia (GO): I - O protólito dos corpos de serpentinito. Revista Brasileira de Geociências, v. 22, n. 3, p. 338-352, 1992.

SUITA, M.T.F. et al. Complexos ofiolíticos do Brasil e a metalogenia comparada das faixas Araçuaí e Brasília. In: PEREIRA, E; CASTROVIEJO, R.; ORTIZ, F. (eds). Complejos Ofiolíticos en Iberoamérica: guías de prospección para metales preciosos. Madrid, Rede CYTED, 379p. cap. 5, p. 101-132, 2004.

TASSINARI, C.C.G. et al. Neoproterozoic oceans in the Ribeira Belt (southeastern Brazil): The Pirapora do Bom Jesus ophiolitic Complex. Episodes, v. 24, n. 4, p.245-251, 2001.

Artigo recebido em 04 de abril de 2011. Aprovado em 13 de setembro de 2011. 